IRA-International Journal of Education \& Multidisciplinary Studies

ISSN 2455-2526; Vol.07, Issue 01 (2017)

Pg. no. 53-62

Institute of Research Advances

http://research-advances.org/index.php/IJEMS

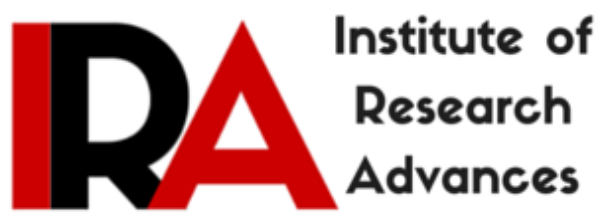

\title{
Teaching Aptitude of Prospective Teachers as Related to Their Level of Aspiration
}

\section{Dr. Kusum Lata}

M.A (English), M.Sc (Chemistry), M.Ed, UGC (NET) in Education, PhD (Education)

Asst. Professor, Rattan Professional Education College, Sohana, India.

Type of Review: Peer Reviewed.

DOI: http://dx.doi.org/10.21013/jems.v7.n1.p6

\section{How to cite this paper:}

Lata, K. (2017). Teaching Aptitude of Prospective Teachers as Related to Their Level of Aspiration. IRA International Journal of Education and Multidisciplinary Studies (ISSN 24552526), 7(1), 53-62. doi:http://dx.doi.org/10.21013/jems.v7.n1.p6

(C) Author.

\section{(c) EY-NC}

This work is licensed under a Creative Commons Attribution-Non Commercial 4.0 International License subject to proper citation to the publication source of the work. Disclaimer: The scholarly papers as reviewed and published by the Institute of Research Advances (IRA) are the views and opinions of their respective authors and are not the views or opinions of the IRA. The IRA disclaims of any harm or loss caused due to the published content to any party. 


\begin{abstract}
The purpose of this study was to find out the relationship between teaching aptitude and level of aspiration of prospective teachers. Hundred prospective teachers were taken from two teacher training colleges of district Mohali and teaching aptitude test battery by Psy-chom Services and level of Aspiration Scale by Bhargava and Shah were administered on them. It was found that teaching aptitude and its variable are significantly related to level of Aspiration which shows the importance of these variables in the selection of teaching profession.
\end{abstract}

Variables Used: teaching aptitude and level of aspiration

\title{
INTRODUCTION:
}

In most walks of life, past performance is the best predictor of future performance in the same realm of activity. The effectiveness of education depends upon the quality of teachers working in an institution which in turn depends upon the quality of training received by them in different training institutions. It is well known that the teaching profession is one of the most important arts of guiding students through a variety of selected teaching methods and methodologies which attract the brightest minds, finest personalities and most committed young people. Teaching profession requires people who have right type of aptitude for teaching and bound to be a successful teacher in future.

\section{LEVEL OF ASPIRATION}

The knowledge of the goal, a person sets for himself, is important for true appraisal of the efficacy of his behaviour and the understanding of his reactions to environmental stress. Such goals may be explicit and formulated by the individual himself who announces for instance, his intension of running a certain miles in a given time or the formulation may come from the environment which prescribes a standard of achievement which the individual has to attain. Alternatively, the goal may be implicit, unformulated and discovered only by studying the individual's subjective experiences of success and failure when he performs tasks of varying difficulties. In view of the difficulty of comparing directly the principal goals in life of individual, the problem has to be narrowed down to enable objective measurement. This is done by using the test of level of aspiration.

People often set goals for their actions, be it to receive professional training or promotions, to achieve highest rank in college or university or to attain highest status in society. Some of these goals can be easily achieved called realistic goals whereas others seem quite unreachable known as unrealistic goals. The notion of goal setting or level of aspiration is borrowed from ordinary language into psychology. This concept has carried out with it connotations of 'purpose', 'objective', the 'thing' towards which the action is directed.

The concept of level of aspiration was first introduced by Hoppe (1930) while making a reference to a degree of difficulty of the goal towards which a person is striving. He defined the level of aspiration as "a person's expectations, goals or claims on his own future achievement in a given task". Hoppe's main measure of the height of level of aspiration was the level of performance at which success was experienced. By this technique, he was able to formulate certain general tendencies that he observed regarding level of aspiration behaviour.

Discussing a person's aspiration level gives us insight into his ideal self, the self that he would like to be. It has an important place in the psychology of personality because it is intimated to the human self, specially the individual self picture, which gives us the knowledge of a person not only as he is but as he would like to be.

In educational field, the aspiration level of an individual is considered as an important motivating factor. It is a frame of reference involving self esteem or alternatively experiences, which 
is the feeling of failure or success. Several other factors like interest, attitude, values, aptitude, creativity and non intellectual factors of personality also influence the level of aspiration. The aspirations during student period also shape their behaviour. An individual's aspiration level represents him not only as he is at any particular moment, but also as what he would like to be at some point in the future. It is a measure of his intentional disposition, an important element of his long range behaviour. By knowing a person's level of aspiration, we learn a great deal about him. So it is necessary to have a good knowledge of the aspiration level of an individual, both from educational and from guidance point of view.

Frhana (2011) described level of aspiration as an expression of the desire to achieve and improve. It is a level of motivation that overcomes task complexity with perpetual efforts and pushes one to work toward those goals.

Godard (2012) defined "Aspiration is what an individual hopes will happen in the future".

Ahmad (2015) stated that the level of aspiration is one of the most important factors for all the students, not only in the field of education but in all life aspects as well, because it is considered the driving force to achieve all her/his objectives.

Ismail and etal (2008) described that teacher is an agent of change in education. Even though most teachers have some kind of goal which they aspire to achieve in their teaching career, but the aspiration of one teacher may not be the same as the aspiration of another teacher. Aspiration, a strong desire and hope in accomplishing a certain aim can be personally motivated. Tytler's (2005) suggested six elements which support prospective teachers' aspirations and their teaching and learning namely: 1) A supportive and productive learning environment, 2) A learning environment which promotes independence, interdependence and self motivation, 3) A learning program which reflects students' needs, backgrounds, perspectives and interests 4) An environment which poses challenge to students and which supports and develop deep levels of thinking and application, 5) Assessment practices which is an integral part of teaching and learning and 6) Learning which connects strongly with communities and practice beyond the classroom.

In teacher training institution, prospective teachers set their aspiration level to achieve the goal of becoming successful teachers after the completion of course. They set their goal at certain standards based on their life experiences, caliber and interest and sincerely do efforts in achieving those goals during their training period which can be clearly observed through their competency in the classroom. Their goal setting behaviour directly related to their learning session to learn teaching skills in order to become efficient teachers.

\section{TEACHING APTITUDE}

Teaching is the process of changing the behavior and developing desirable skills in learner for his all round development. The process of teaching to be conducted effectively depends upon effective teachers. No development of new technology can revolutionize the classroom teaching unless capable and committed teachers are there in teaching profession. The success of a teacher depends on his self-control, good teaching aptitude and work oriented mind.

Singh (2015) believed that no nation can rise above the level of its teachers and it is the teacher who plays pivotal role in the educational system and is a catalytic agent of change in the society. A teacher should not only be competent in his subject, teaching methods, understanding the learner but also has a favourable aptitude towards teaching profession. It is well said that if aptitude refers to "quality of being fit for a purpose or position", then teaching aptitude is the quality of being fit for teaching profession. That is why, it is considered as the introductory determinant factor of effective teaching. Babu and Rao (2007) suggested that if the teachers are empowered with necessary skills and competencies, they can inculcate the skill in other persons and mainly in pupils. 
A teacher with teaching aptitude encourages students to use active techniques to create more knowledge and then to reflect on and talk about what they are doing and how their understandings are changing. Researchers suggest that teacher's knowledge of subject matter, student's learning and teaching methods are important elements of effective teaching, which are very much related to teaching aptitude. Although an educational system has excellent resources, but if the teachers are lacking teaching aptitude and are incompetent or indifferent to their responsibilities, the whole program is likely to be ineffective and largely wasteful. Anees (2005) has provided substantial evidence favouring teaching aptitude, for quality education. A modern view of teaching aptitude includes professional activities on the school level, such as co-operating in teams, building professional learning communities, participating in school development, and evaluating and changing working conditions. These activities shape the learning environment on the school level, i.e. the school climate, ethos and culture, and thus directly and indirectly (via classroom-level processes) affect student learning.

Dictionary in English (2011) enumerated that teaching aptitude means probability of success in teaching. Whereas, Kumar (2012) considered the teaching aptitude means an interest in the teaching work orientation, implementing teaching principles and methods.

Kaur (2014) described teaching aptitude as a specific capacity or special ability, distinct from the general intellectual ability of in individual, indicative of his probable success in a particular field after receiving appropriate opportunity for learning or training.

A constructivist teacher's role is to foster and direct his work on the part of students. A teacher with teaching aptitude encourages students to use active techniques to create more knowledge and then to reflect on and talk about what they are doing and how their understandings are changing. Research indicates that everyone does not have the ability or the aptitude to take up teaching. Certain minimum requirements in the way of intelligence, temperament, and personality are observed to be highly critical.

Hence, teaching aptitude is considered as the determinant factor for choosing the teaching profession. When we say a person possesses an aptitude for teaching, it is assumed that he has a good proportion of the traits required for becoming successful in teaching. Ghatvisave (2012) also stated that the success in teaching and satisfactory preparation of teaching profession is only possible to those people who have remarkable aptitude in teaching.

Teaching aptitude and level of aspiration are two important variables of teaching learning process which directly or indirectly influences the teaching behaviour of all the teacher trainees. Aptitude is considered to be an important characteristic of an individual, which predict the future success or failure of teachers, whereas, level of aspiration means a "strong desire to accomplish something". In teaching profession, it is the pupil teachers' expectations, goals or claims on their future achievement and shows the estimation of these trainees' abilities for their future performance and the efforts they make towards attaining the goals. If the teacher trainees do not have the required aptitude and aspiration then no amount of training can influence their teaching effectiveness in the classroom. These two variables greatly influence their acquisition of teaching skills during their training period.

\section{REVIW OF LITERATURE}

Dabir (1986) examined vocational aspirations as a function of aptitudes, and motivational patterns among the boys and girls studying in 9th, 10th and 11th grades in Nagpur District and made an effort to study how aptitudes, motivation, socio-economic status and aspirations were related to one another. It was found that vocational aspirations were partially consistent with aptitudes. Vocational aspirations were not merely a function of aptitudes but a function of the socioeconomic status of the subjects. The positive and significant values of correlation between vocational aspirations and achievement motivation suggested that achievement motivation was likely to generate the vocational aspirations of the subjects. 
Joshi (2003) studied teaching aptitude of higher secondary school teachers of Gujarat state in context of some psycho-socio variables and found that the main difference on teaching aptitude scores was in favour of trainees having low leadership trait. It was also noted that leadership and vocational aspiration did not interact with each other on teaching aptitude. The trainees having low emotional stability were found superior to their counterparts on teaching aptitude, whereas, the trainees having high aspiration were found superior to their counterparts on teaching aptitude.

\section{TITLE OF THE STUDY}

\section{TEACHING APTITUDE OF PROSPECTIVE TEACHERS AS RELATED TO THEIR LEVEL OF ASPIRATION}

\section{OBJECTIVES OF THE STUDY}

The objective of the study gives direction to the study and keeps the investigator focused in due course of time. The study was conducted to attain the following objective:

- To study the relationship between different variables of teaching aptitude and aspiration level of prospective teachers.

\subsection{HYPOTHESES}

- There exists no significant relationship between different variables of teaching aptitude and level of aspiration of prospective teachers.

\subsection{DELIMITATIONS OF THE STUDY}

The present study had the following delimitations.

- Only hundred prospective secondary schools teachers were selected for the present study.

- Only two Colleges of Education (B.Ed) in District Mohali were selected for the study.

- The scope of present study was delimited in respect of sample used, the variables, tools employed to measure the variables and statistical techniques for analysis. The area of study was restricted to Mohali District only.

\section{DESIGN OF THE STUDY}

The study aimed at studying the relationship between levels of aspirations and teaching aptitude of prospective teachers. In this study, the independent variable is the teaching aptitude and dependent variable is level of aspiration.

\section{SAMPLE}

The sample for the present study consisted of hundred prospective teachers. They were drawn from two education colleges of Mohali in Punjab which were affiliated to Punjabi university, Patiala and were recognised by NCTE and state government. Both the colleges were fulfilling the basic requirement for the present study. They had the same course of study/syllabus and got admitted through the same procedure of admission.

\section{TOOLS USED}

The following tools were used to conduct the present study:-

- $\quad$ Level of aspiration test by Bhargava and Shah (1996).

- $\quad$ Teaching aptitude test battery by Psy-Com Services(1996) 


\section{PROCEDURE OF THE STUDY}

The investigation started by administering the teaching aptitude scale and level of aspiration scale on all prospective teachers. The scoring was done of both these scales on the basis of instructions given in the manual.

\subsection{STATISTICAL TECHINIQUES USED}

The following statistical techniques were employed to analyze the data

- Descriptive statistics i.e. mean, median, Standard Deviation, skewness, kurtosis were used to know the nature of the sample of distribution of scores with respect to various variables taken for study.

- $\quad$ Coefficient of correlation was calculated to find out the relationship between variables teaching aptitude and level of aspirations

\section{ANALYSIS AND INTERPRETATION OF DATA}

Frequency Distribution of scores of level of Aspiration of prospective teachers

\begin{tabular}{|l|c|c|c|c|c|c|c|}
\hline $\begin{array}{l}\text { Statistics } \\
\text { Variables }\end{array}$ & $\mathbf{N}$ & Mean & $\begin{array}{c}\text { S.E. of } \\
\text { Mean }\end{array}$ & Median & $\begin{array}{c}\text { Standard } \\
\text { Deviation }\end{array}$ & Skewness & Kurtosis \\
\hline $\begin{array}{l}\text { Statistics } \\
\text { Values }\end{array}$ & 100 & 5.46 & 0.17 & 5.00 & 1.71 & 0.33 & 0.13 \\
\hline
\end{tabular}

Frequency polygon showing frequency distribution of scores of level of Aspiration for the sample of prospective secondary school teachers

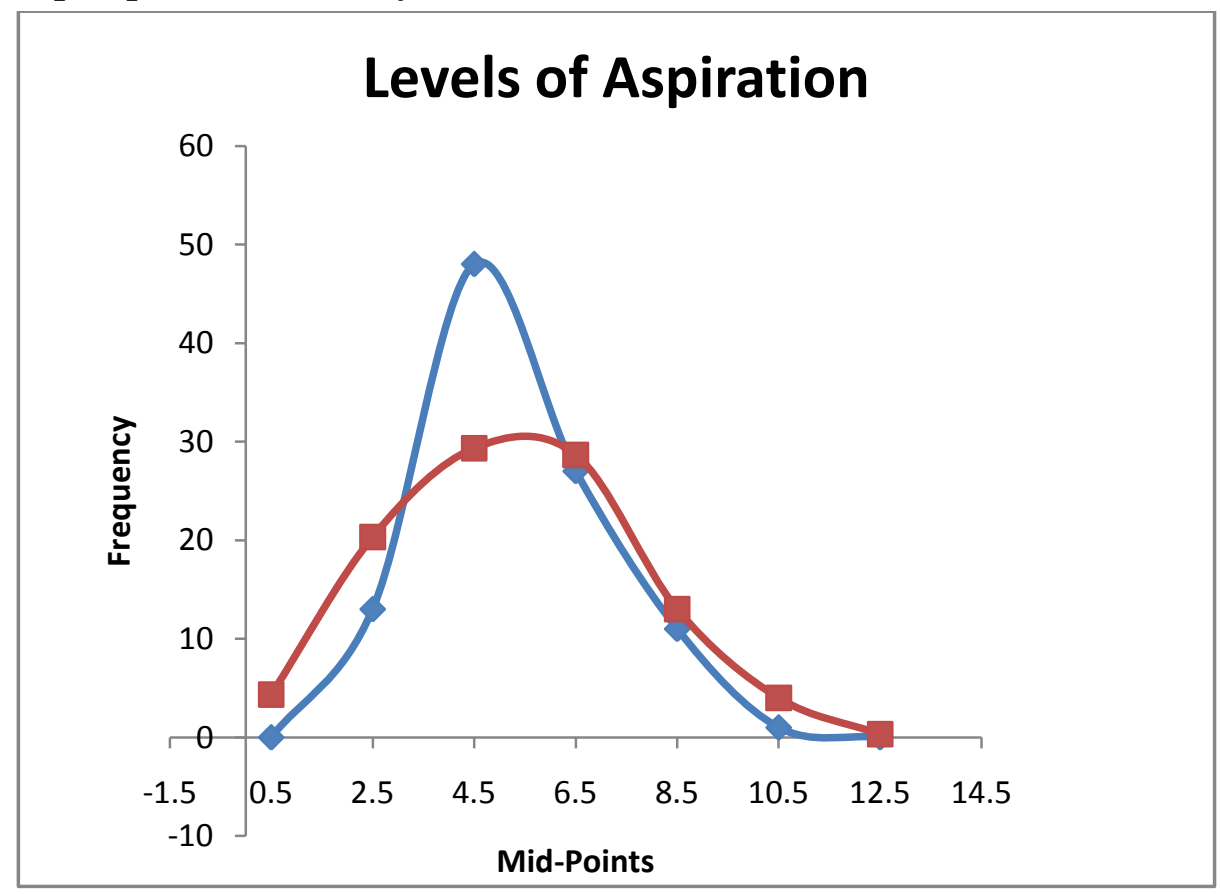

\section{Interpretation and discussion of above table}

The above table depicts that mean score of level of aspiration of prospective teachers is 5.46 and median is 5 . The frequencies pile up slightly on left side of the curve which is supported by the value of skewness (0.33) which is slightly lofty. The value of kurtosis (0.13) also indicates the very much leptokurtic nature of data which is also shown by the frequency polygon shown in figure. Thus scores 
of aspiration are distributed slightly away from normal distribution of scores among the sample of prospective secondary school teachers.

Descriptive statistics for teaching Aptitude scores of prospective teachers.

- Table Frequency Distribution of Teaching Aptitude (Total) of prospective teachers

\begin{tabular}{|l|l|l|l|l|l|l|l|}
\hline $\begin{array}{l}\text { Statistics } \\
\text { Variables }\end{array}$ & N & Mean & $\begin{array}{l}\text { S.E. of } \\
\text { Mean }\end{array}$ & Median & $\begin{array}{l}\text { Standard } \\
\text { Deviation }\end{array}$ & Skewness & Kurtosis \\
\hline Statistics Values & 100 & 117.73 & 2.20 & 117.00 & 22.00 & 0.001 & -0.69 \\
\hline
\end{tabular}

- Figure: Frequency polygon showing frequency distribution of scores of teaching aptitude for the total sample of prospective teachers

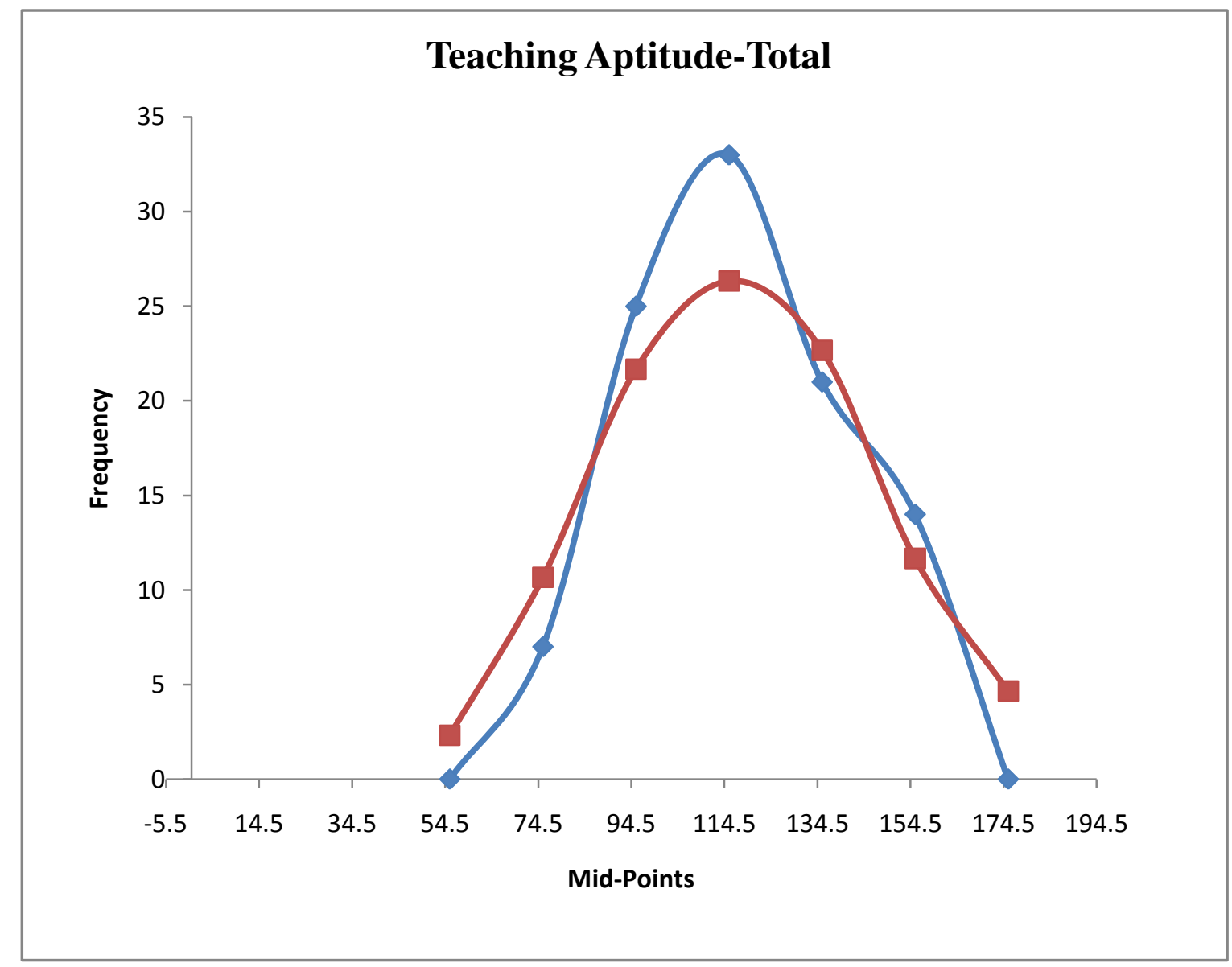

\section{Interpretation and discussion based on Table}

The mean scores of teaching aptitude of prospective teachers is 117.73 and median 117 which are quite close to each other indicating nearly normal distribution of the scores. The values of skewness (0.001) indicates that the distribution is almost normal and the value of kurtosis $(-0.69)$ indicates a leptokurtic curve. The scatter diagram shown in figure above also affirms the same and indicates a close to normal curve as frequencies do not pile up on either side. The same is supported by frequency polygon shown in figure. Thus teaching aptitude is normally distributed the sample of prospective secondary school teachers. 


\section{INTERPRETATION AND DISCUSSION OF DATA:}

Objective: To study the relationship between teaching aptitude and aspiration level of prospective teachers.

Hypothesis: There exists no significant relationship between teaching aptitude and aspiration level of prospective teachers.

Coefficients of correlation for the Dimensions of teaching aptitude and level of aspiration for prospective teachers $(\mathrm{N}=100)$

\begin{tabular}{|l|c|c|}
\hline Variables & Pearson Correlation & Sig. (2-tailed) \\
\hline Communication Skill and level of Aspirations & $0.701^{* *}$ & .000 \\
\hline General Intelligence and level of Aspirations & $0.447^{* *}$ & .000 \\
\hline Maturity and level of Aspirations & $0.762^{* *}$ & .000 \\
\hline Perceptive and level of Aspirations & $0.717^{* *}$ & .000 \\
\hline Persistence and level of Aspirations & $0.749^{* *}$ & .000 \\
\hline Receptive and level of Aspirations & $0.588^{* *}$ & .000 \\
\hline Social Warmth and level of Aspirations & $0.668^{* *}$ & .000 \\
\hline Teaching Interest and level of Aspirations & $0.600^{* *}$ & .000 \\
\hline $\begin{array}{l}\text { Teaching Aptitude (Total) and level of } \\
\text { Aspirations }\end{array}$ & $0.956^{* *}$ & .000 \\
\hline
\end{tabular}

*Correlation is Significant at 0.05 level $* *$ Correlation is Significant at 0.01 level

The above table reveals the Pearson coefficient of correlation on dimensions of teaching aptitude and level of aspiration of prospective teachers. The perusal of table shows that all the dimensions of teaching aptitude positively and very highly significantly correlate with aspirations. This implies that teaching aptitude affects the aspirations and in turn gets affected by the aspirations of the prospective teachers. Thus the hypothesis that there exists no significant relationship between teaching aptitude and level of aspirations of prospective teachers is not accepted. The data did not support the hypothesis.

\section{FINDINGS AND CONCLUSION}

Finding 1: It was found that all the variables of teaching aptitude are positively and significantly related to level of aspirations of prospective teachers

\section{EDUCATIONAL IMPLICATIONS}

It is well known that training in every field results in improving the performance of the learner. It not only improves his/her skills but also build confidence among the person. In our daily life we always try to learn new things by getting knowledge and training in the respective field. Without getting necessary information or knowledge no one can become efficient and this efficiency can be acquired through appropriate training.

The theory behind this study reiterates the predictions to become successful teachers; prospective teachers should have positive relation between their level of aspirations and teaching aptitude. By analyzing the whole results, the researcher found out that there was high significant and positive relationship between teaching aptitude and level of aspiration showing the importance of these variables during the teacher training course. The students should get admission in teacher training courses after checking their entry behaviour by administering teaching aptitude and level of aspiration scale in order to find out how much they are serious in adopting the teaching profession and 
so that after the completion of training, they would be able to become efficient, confident and qualified teachers.

\section{References}

- Ahmed, Ismail Sadiq Abdulwahed (2015) retrieved from http: shodhganga.inflibnet.ac.in/ bitstream/10603/1552/9/09_chapter\%202.pdf

- Anees (2005) Anees, M. (2005). A Comparative Study of Formal and Non-Formal Systems of Teacher Education in Pakistan. Institute of Education and Research, University of Arid Agriculture, Rawalpindi, Pakistan. (Unpublished Ph.D. Thesis)

- Babu and Rao (2007) Bhaskara, Digumarti Rao, Kuchipudi Bujji Babu. (2007) Teaching Aptitude of Primary School Teachers. New Delhi, Sonali Publications.

- Dabir, D. (1986), A Study of Vocational Aspirations as a Function of Aptitude and Motivational Patterns among the Boys and Girls Studying in 9th, 10th and $11^{\text {th }}$ Grades in Nagpur District. Ph.D. Education, Nagpur University.

- Dictionary in English (2011) https://en.oxforddictionaries.com/definition/aptitude

- Frhana,S (2011)Anxiety as Predictor of Aspiration among Academic Achievers, The Online Journal of New Horizons in Education, Volume 3, Issue 4,12-23.

- Ghatvisave and Siddharth (2012) Co-Relation between Teachers Effectiveness and Teaching Aptitude. Global Online Electronic International Interdisciplinary Research Journal (GOEIIRJ) \{ Bi-Monthly\}. ISSN : 2278 - 5639 , Volume-I, Issue-I June 2012 www.goeiirj.com

- Godard, Peter Davies., Stephen, Gorard., \& Beng Huat See(2012) The impact of attitudes and aspirations on educational attainment and participation. http://www.jrf.org.uk/sites/files/jrf/education-young-people-parents-full.pdf

- Ismail ,Habsah .Konting ,Mohd. Majid .Ali ,Wan Zah Wan .Hassan ,Roshafiza (2008) Comparison of Teachers' aspiration towards change in teaching and learning and the implementation of their teaching practice. Department of Foundations of Education, Faculty of Educational Studies, Recent Advances In Neural Networks, Fuzzy Systems \& Evolutionary Computing, Malaysia

- Joshi, K. (2003) Teaching Aptitude of higher secondary school Teachers of Gujarat State in context of some Psycho-socio variables. Ph.D. (Edu), Gujarat University.

- Kaur, Harmeet.(2014) A Comparative Study of Teaching Aptitude of B.Ed.(General)Pupil Teachers of Kurukshetra District in relation to their Gender, Location, Stream and Professional Experience Education. INDIAN JOURNAL OF RESEARCH .Volume: 3, Issue: 8 August 2014 ISSN - 2250-1991 20.

- Kumar,Sunil and Gupta,Mohan (2012) A Comparative Study of Level of Educational Aspiration of Secondary Class Students of Government and Non-Government Schools. International journal of technical and non technical research, volume issue January 2014. eISSN 0976-7967,p-ISSN 2319-2216

- Parkash, Ved. (1987) Student Aspiration-Some misconceptions,. New Delhi: Mittal Publication. 
- Singh K (2015). Teaching Aptitude of B.Ed. Teacher Trainees of Himachal Pradesh in Relation to Their Gender and Stream. International Journal of Academics and Research in Education. http://www.academicresearchjournals.org/IJARER/PDF/2015/October/Singh.pdf

- Tytler, Russel. (2005) School Innovation in Science: Change, Culture, Complexity, in K. Boersma et al (ed.), Research and the Quality of Science Education, pp. 89-105, Springer, Berlin. 